\title{
APPEARANCES OF DISABILITY AND CHRISTIANITY IN UGANDA
}

\author{
TYLER ZOANNI \\ University of Bayreuth \\ (D) https:// orcid.org/0000-0003-2519-107X
}

Unfailingly, whenever I greeted Maimuna, she would ask me for a photograph: Kuba ekifaananyi, she would insist, using the Luganda idiom for photography ("strike an image"). ${ }^{1}$ With graying, short-cropped hair, and likely in her forties, Maimuna is a Ugandan woman who lives in L'Arche, which is Uganda's only dedicated home for people with cognitive disabilities, and part of a transnational Catholic network of such homes. ${ }^{2}$ I would always comply with Maimuna's request, take out my phone, snap the photo, and show her, while she would respond with a shriek of delight.

I was puzzled by the requests, because Maimuna does not own a phone or other means of viewing the photos. I finally asked Maimuna the question that felt obvious yet impertinent: Why did she demand the photographs? I had anticipated she might say something about enjoying seeing herself. Instead, Maimuna declared that she wanted to "help." Perplexed, I asked how; Maimuna responded that I would show the pictures to my friends in the United States, and that this would inspire them to "help the children" in L'Arche.

Maimuna's understanding of these cell-phone photos remains with me, and not simply because her aspirations to circulate her image as a way to affect others departs from Euro-American critiques of inspiration and pity as problematic 
frames for disabled people (Young 2012; cf. Livingston 2006). Maimuna sees her images as capable of moving others and eliciting material benefit that would arrive through networks I embodied. She held this theory without telling me and had drawn me into reproducing her image unwittingly. Wittingly, I have done so once more here.

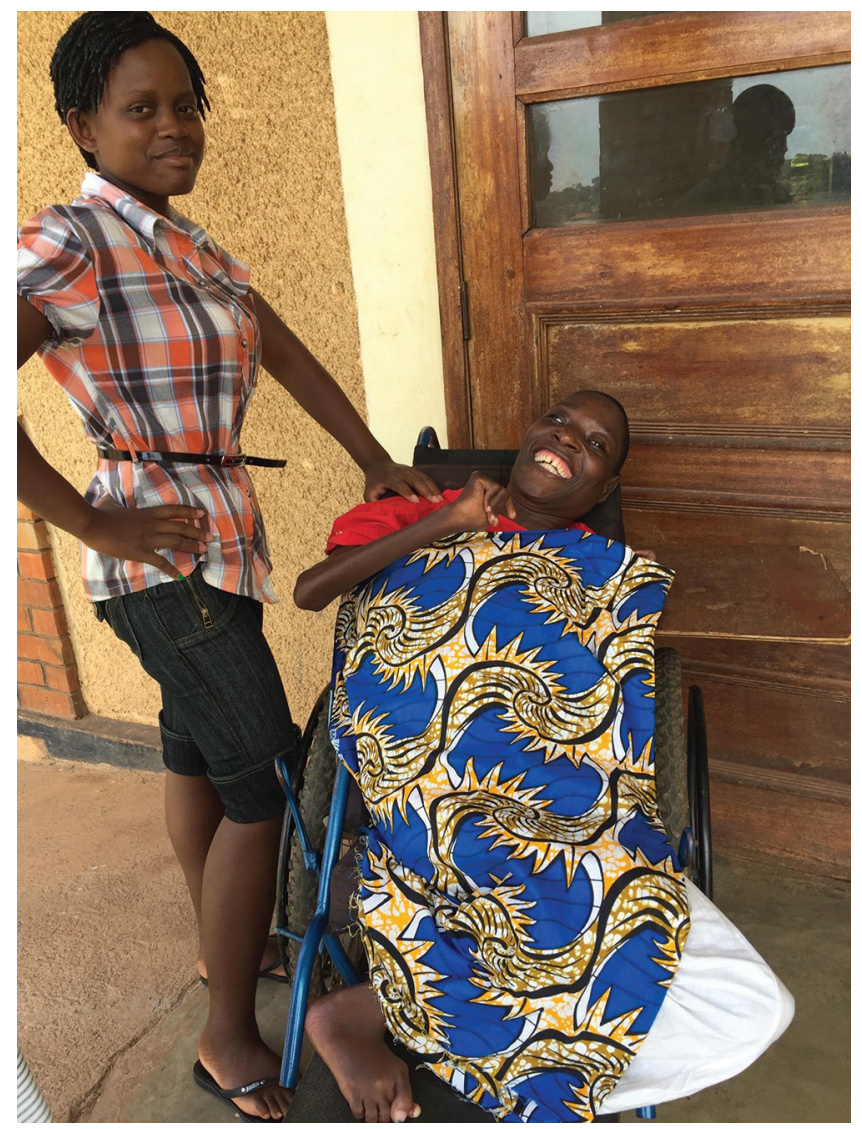

Figure 1. In one of the countless photos Maimuna asked me to take, she poses with a L'Arche staff member. Photo by Tyler Zoanni.

Maimuna, one might say, demanded what Judith Butler $(2015,25)$ has called "the right to appear," though for reasons that will become clear, right and its liberal connotations are not the best frame for the kind of disability politics that Maimuna's call for charitable help implies. Butler is one of a cluster of recent thinkers (e.g., Rancière 1999; Nancy 2000; Seel 2005) who have drawn on Hannah Arendt's (1998) discussion of appearance. For Arendt (1998, 50), the possibility of appearing — that is, "being seen and heard by others as well as ourselves" — constitutes the distinctiveness of human beings and the basis for meaningful political ac- 
tion. Though certain aspects of Arendt's discussion of appearance fit with regnant tropes of liberal identity politics (e.g., having voice, being seen), her account gestures at a vision of social and political life irreducible to claims about identities, rights, and self-representation. Arendt's discussion also works self-consciously against an idealism deeply engrained in Western thinking at least since Plato, an idealism that distinguishes between "(true) being and (mere) appearance" (Arendt 1981, 23) and denigrates the latter as a deceptive impediment to understanding the former.

Yet if Arendt's notion of appearances challenges some central assumptions within Western thought, it resonates with a sensibility that is widely evident in Uganda, a social aesthetics that we see in Maimuna's desire to be photographed. Arendt's concern with appearance thus serves in this article as an analytic device, helping to name and thematize key dynamics of social life in Uganda. In turn, attention to disability helps us appreciate the highly fraught nature of appearance as an aspiration for those who - in the way they sound, look, and act - prove highly disturbing to many people. Such attention underscores the fact that the capacity to appear is unevenly socially distributed, far more readily available to the kinds of humans who fit into dominant expectations about minds and bodies and how they are supposed to look and act in public life. The efforts that I consider in this article not only acknowledge the force of appearance in Uganda; they also work to challenge some of its exclusions.

At first glance, disability appears quite prominently in Uganda. The country has some of the most progressive disability laws in the world, such as mandated representation for people with disabilities at every level of government, including five reserved seats in parliament. Additionally, Uganda is home to a vibrant disability activist community that focuses on mobility and sensory disabilities (Abimanyi-Ochom and Mannan 2014). As will become clear below, Uganda's progressive laws and assertive activists follow liberal logics of self-representation, and it is precisely these liberal logics that have had excluded large swathes of disabled Ugandans. Thus, in contemporary Uganda, there is dedicated disability media coverage on television, on radios, and in newspapers, but the country's disability laws are often not enforced or funded, and they have made little difference for the material circumstances of the vast majority of disabled Ugandans. What is more, issues relating to cognitive disability disappear in national conversations. In this context of relative neglect, Christian groups provide almost all of what little dedicated care and advocacy exist for Ugandans with cognitive disabilities.

This article's account of appearance, cognitive disability, and the efforts of Ugandan Christian groups serves to advance an emergent anthropology of disabil- 
ity, as well as the interdisciplinary field of disability studies. Important paradigmatic efforts have sought to establish that disability constitutes a form of human difference as fundamental as more well-studied matters like race, class, gender, and sexuality (Kasnitz and Shuttleworth 2001; Ginsburg and Rapp 2013). Anthropologists have attended, for example, to novel forms of disability kinship (Landsman 2009; Rapp and Ginsburg 2011), sociality (Ochs and Solomon 2010), and citizenship (Das and Addlakha 2001; Rapp and Ginsburg 2001; McKearney 2017); the economic and political activities of people with mobility disabilities (Kohrman 2005; Whyte and Muyinda 2007; Phillips 2011; Devlieger 2018); Deaf social worlds and activisms (Nakamura 2006; Friedner 2015); the sexual lives of disabled people (Kulick and Rydström 2015); the emergence and globalization of new disability categories (Grinker 2007); the aftermath of disabling violence (Ralph 2012; Wool 2015); and the ways in which the rhetoric of disability politics may be co-opted (Friedner 2017; Hartblay 2017). Much like the interdisciplinary field of disability studies (Barker and Murray 2013; Grech and Soldatic 2016), however, this research has largely focused on disability in the global North in the context of what Elizabeth A. Povinelli $(2002,5)$ calls the "liberal diaspora," where disability as a social category and disability politics both arise through the grids of rightsbased claims-making and identity politics, as well as through highly secular visions of agency, politics, and belonging (Staples and Mehrotra 2016; Friedner 2018; Friedner and Zoanni 2018).

Against this backdrop, I explore the contours of a nonsecular, nonliberal politics of disability made possible by Ugandan Christian efforts. This exploration brings into view forms of disability collectivity and publicity beyond the highly secular, Euro-American frames that tend to dominate disability studies. It also expands the forms of human difference that appear in scholarly and political attention focused on disability. As Don Kulick and Jens Rydström (2015, 15) note, the field of disability studies has tended to ignore "the most significantly disabled" in favor of "the kinds of politically aware, combative, independent, and articulate disabled subjects who have always been at the center of both disability activism and academic disability studies" (see also McKearney and Zoanni 2018). In other words, disability politics and activism privilege a particular vision of the person, which might be quite reasonably named as the liberal individual. In turn, this reliance on a liberal vision of the person so as to recuperate certain disabled subject positions effaces people like Maimuna, who can never appear as such.

The analysis that follows is grounded in two Christian institutions: L'Arche and Special Children's Trust (SCT), respectively a Catholic home and a Pentecostal 
school that are the oldest and largest institutions of their kind in Uganda. Using a set of comparisons (Englund 2000; Robbins, Schieffelin, and Vilaça 2014; Scherz 2014), the article traces points of similarity and difference between these two Christian institutions, as well as between Christian and secular disability politics in Uganda. These comparisons bring into view the different modes of disability appearance that L'Arche and SCT foster, while underlining something they share: the construal of people with cognitive disabilities as "children," as Maimuna herself put it above. This appearance of people with cognitive disabilities as children becomes the basis for constituting them as persons beyond the realm of self-representation, something privileged in Uganda's national disability politics. All of this may be stated quite simply: Even as Christian paternalism in response to cognitive disability may appear deeply repugnant to a liberal vision of disability politics, it sustains a disability appearance in Uganda that is otherwise not possible.

\section{THE WILL TO APPEAR}

Maimuna sees the cultivation of a certain form of publicity as beneficial for L'Arche, the Catholic home where she lives. She views cell-phone images of disabled L'Arche residents as capable of inspiring people to help. That Maimuna should turn to images and the visual as a vehicle for publicity is notable insofar as the sight of people like Maimuna frequently proves disturbing in Uganda - this much is apparent in the unabashed gawking that Maimuna draws in public settings, as well as in the fact that people like Maimuna are rarely seen in such settings.

An important conversation within disability studies understands aesthetic matters as fundamental to political and social life. Julie Livingston (2008), writing about Botswana, has powerfully explored the ways in which the visceral aesthetics of atypical bodies challenge the ideological abstractions of both African humanist and liberal rights discourses. More generally, a range of scholars examine the ways that "extraordinary bodies," as the cultural critic Rosemarie Garland-Thomson (1997) puts it, draw intense visual scrutiny from the nondisabled (Bogdan 1988; Adams 2001; Schweik 2010). Garland-Thomson (2009) further argues that while staring is often stigmatized as a form of rudeness in North America, it can also be the basis of ethically and politically transformative encounters with disability, an opportunity to reckon with and be challenged by embodied human difference. Recent anthropological conversations broaden this concern with the visual, exploring the important role of mass-mediated images and narratives produced by and about disabled people in redefining the meanings and values of disability in North America (Rapp and Ginsburg 2007; Ginsburg 2012). 
Though Maimuna's efforts to appear through my cell-phone camera surprised me, perhaps they shouldn't have, and not only because of Arendt: These efforts reflect assumptions fundamental to the social aesthetics of Buganda, a kingdom in south-central Uganda that comprises the country's largest ethnic group. By social aesthetics I mean norms and assumptions about what human life and collectivity should look and feel like (Brenneis 1987; MacDougall 1999; Elisha 2008). Anyone who spends even a short time in Buganda will notice some of the key dynamics of Ganda social aesthetics: often highly ritualized forms of display are central to a variety of important social transactions - events like meetings, weddings, bar outings, burials, church services - where the public presentation of people and relationships is enacted and foregrounded in various ways (by being commented on, announced, described, etc.). The very organization of the built environment is structured to enable such presentations: the courtyards of the churches, houses, palaces, and hotels that serve as the primary venues for social gatherings and public functions all feature large amounts of centrally located open space affording display. $^{3}$

These settings enable the crucial displays of self that have been and remain important for social life across precolonial, colonial, and postcolonial moments. From the nineteenth century and into the twentieth, British observers - missionaries and anthropologists alike — were struck again and again by Ganda investments in what Audrey I. Richards (1964b, 297) described as a "general concern with appearances." She went on to observe:

There is a dignity and gravitas about public life which is characteristic, and within the house, before a visitor, great attention to decorum and displayfor instance to the nice arrangement of each embroidered table cloth or lace mat and to the setting out of dishes or tea cups. Europeans are often criticized in such homes if they appear in dishevelled or casual clothes or behave in slap-dash fashion. (Richards 1964b, 298)

Mid-twentieth century Ganda elites often found Europeans unacceptably sloppy in, for example, their penchant for shorts and safari gear (Richards 1964b, 288), while Europeans, for their part, were impressed by elegant tea services, elaborate royal pageantry, and imposing construction projects in Buganda (Hattersley 1908, 7; Richards 1964a, 274-75; Kodesh 2001).

Today, major events of life in Buganda continue to foreground people displaying restrained and refined speech, charisma, and poise. These appearances 
constitute moments in which productive, hierarchical, and properly regulated relationships are made visible and affirmed (cf. Summers 2006; Peterson 2012, 19, 78-104). Such appearances prove central to fostering exchanges of sentiment and money; to facilitating life-cycle transitions like graduations, baptisms, and marriages; and to maintaining the networks of obligation and interdependence that are central to Ugandan social life (Scherz 2014). Appearing as socially and biologically reproductive is particularly important (Boyd 2013), as are physical features, the body, and its adornment; people put a great deal of effort into matters like thoroughly cleaned and pressed clothing, shining skin, and neatly groomed bodies, all difficult tasks in an often hot and dusty environment.

It is in this work of appearance that people come to embody and publicly display visions of normative personhood. A canonical (and by now perhaps conventional) anthropological observation is that, in contrast to ideologies of the individual, people in many parts of Africa are not imagined as prior to or separate from their relationships with others. Instead, connection to and reliance on others is understood as a central aspect of personhood (see Comaroff and Comaroff 2001). Yet even highly relational visions of personhood, like visions of personhood everywhere, presuppose a normative trajectory of development, maturation, and socialization, and it is just such a trajectory that cognitive disability frustrates (Zoanni 2018).

Indeed, someone like Maimuna can never appear as a person is supposed to in a place where appearances matter deeply and on many fronts. In her markedly unconventional life trajectory as well as her manifestly non-normative body and speech, she violates Ganda scripts for being an adult, for being a woman, and for being human. And even normatively embodied Ugandans with cognitive disabilities prove disturbing insofar as they do not use language or behave in expected ways. People often speculate that such pronounced forms of disability result from spiritual trouble such as witchcraft. There is also a common notion that some conditions are transmissible, capable of circulating through saliva, blood, and urine. Epilepsy, in particular, is thought to be contagious, but generalized anxieties arise in the face of any form of pronounced disability: these always posed a potential to harm others insofar as they could spread a spirit, witchcraft, or other vectors of spiritual affliction.

For all these reasons, appearance is fraught terrain for someone like Maimuna. Nonetheless, she works within the logics of the social aesthetics that her appearance violates, logics in which displays of self can do transformative social work. In this way, a sense of Ganda social aesthetics helps us appreciate the stakes 
of Maimuna's own presentation of self and her bid to appear via my cell-phone photos to an imagined audience of my friends in the United States. Her efforts reflect the idiosyncrasies of Maimuna's personality, to be sure, but they are not isolated; instead, such efforts form part of larger sets of institutionalized ways in which organizations like L'Arche and SCT work to make cognitive disability appear. I will come back to these efforts in a moment, but first, to underscore their distinctiveness, I consider the ways that secular and liberal politics make cognitive disability disappear in Uganda.

\section{LIBERAL DISAPPERANCES}

“Children are persons too!” exclaimed Florence. It was a muggy Saturday morning in June 2017, and Florence was furious. The director of SCT, Uganda's largest and oldest school for what the born-again (balokole) Christians who run it term "special needs," Florence is normally a reserved, even reticent person. But this morning she had lost her patience with Fred, a representative from the $\mathrm{Na}$ tional Union of Disabled Persons in Uganda (NUDIPU). Fred, in the course of explaining NUDIPU's history, structure, and principles, had emphasized that it was difficult to imagine how children's organizations could ever be NUDIPU members, since they were not run by disabled children themselves. How could organizations that did not involve disabled self-representation - organizations that were for but not of disabled people - be a part of NUDIPU?

That Saturday morning, leaders of most of Uganda's ten or so dedicated homes and schools for people with cognitive disabilities had joined Florence in NUDIPU's tin-roofed conference room, under a large banner declaring in assertive capital letters: “DISABILITY IS NOT INABILTY.” These individuals had traveled from throughout the country to Kampala, Uganda's capital and largest city, to attend the meeting, a discussion about how these groups could participate in NUDIPU. What they found was not promising. The tension in the room was palpable, and many who did not speak were angrily rocking in place, sighing, whispering to neighbors, or rolling their eyes. Another group's leader, herself the mother of a disabled child, snapped that it sounded like NUDIPU did not "care." With biting sarcasm, she offered to show the NUDIDU staff person a photo of her son on her phone in case he was not convinced how much "need" there was. Fred apologetically said that he was not defending the situation, only being realistic about it. The meeting ended with cake and sodas, which lightened the mood a bit, but the conversation did not move beyond its impasse, and people left muttering. 
The impasse at that Saturday morning meeting manifests the wider dilemma of national disability politics in Uganda, as well as the liberal logics on which it relies. In 1987 NUDIPU came into existence when a wide range of regionally based disabled persons' organizations (DPOs) focusing on physical disabilities, blindness, and deafness together formed a national umbrella organization. This moment occurred as Uganda returned to a measure of stability following decades of ongoing conflicts, with current president Yoweri Museveni's National Resistance Movement (NRM) the new ruling party. The notion of self-representation was central to the formation of NUPIDU. As one of the organization's brochures put it:

Before the formation of NUDIPU in November 1987, persons with disabilities (PWDs) in Uganda were not involved in the planning and implementation of programmes meant to benefit them. Mainstream programmes and the environment were constructed/designed in a manner that depicted lack of recognition and sensitivity to the needs of PWDs. The services provided emphasized separation of PWDs from the communities and were seen as the preserve for charity endeavours. This scenario obscured and isolated disability issues from the society's main concerns[;] . . . created dependency on institutions; stifled individual initiatives, killed the morale, self-esteem and confidence amongst PWDs. By establishing NUDIPU, the founders aimed at creating a unified voice to challenge the above situation, embark on a systematic and long drawn out struggle to gradually free persons with disabilities from the bondage that reduced them to sub-humans.

Such an account advances an emancipatory narrative premised on a liberal logic of self-representation. The brochure suggests that both the built environment and charitable programs for disabled Ugandans proved oppressive precisely because they were governed by the perspectives of the nondisabled. The ostensible solution to this problem - the project of liberating people with disabilities from "bondage" and "sub-human" status_ _ involved moving beyond "charity endeavours" while making sure that "persons with disabilities" were "involved in the planning and implementation of programmes meant to benefit them."

This logic became central to Ugandan disability politics in the context of explicit state recognition in the late 1980s. When Museveni's NRM came to power, it pursued an agenda of empowering so-called "vulnerable" groups like women, youth, and people with disabilities. Activists took advantage of this state support to begin building disability organizations at a national level. Members of Uganda's 
founding generation of disability activists tend to be urban and highly educated. In contrast to people like Maimuna, these activists are able to engage in social and economic life relatively fully, even as their unconventional bodies may raise questions about their capacities to be productive persons (see Sentumbwe 1995). Often, they are the products of the very schools and charitable institutions they set out to challenge. Reflecting this early leadership, and as is the case for disability activism in many parts of the world, the concerns of adults with physical disabilities, deafness, and blindness define disability activism in Uganda today.

In contrast, Ugandans with cognitive disabilities remain largely excluded from national disability politics. No one active in NUDIPU or in any of the mandated disability seats in parliament has a cognitive disability. The parents, caregivers, and guardians of people with cognitive disabilities are also excluded from participation in groups like NUDIPU, on the grounds that representation of disabled people by the nondisabled would violate the principle of self-representation. Moreover, cognitively disabled people largely do not benefit from the series of special-education laws that Uganda's parliament began to pass in the late 1990s. In principle, these laws guarantee a free education for all children with disabilities. In practice, like national disability activism itself, the disabled people who benefit from these legal guarantees are those children with physical impairments, blindness, or deafness who can otherwise perform in schools, completing national exams and classroom assignments. In contrast, as one government official told me, children with cognitive disabilities have far too "severe" problems to need or benefit from formal education.

In this way, mainstream disability politics in Uganda facilitates the erasure of both children and adults with cognitive disabilities as persons with entitlements to recognition and resources. Beyond that one angry Saturday morning meeting, I rarely heard cognitive disability emerge as a topic in NUDIPU meetings or disability NGO forums that I attended while doing fieldwork. When I asked the director of NUDIPU why people with cognitive disabilities remained without representation in the organization, he told me that until "self-advocacy" took off among such "populations," there would be no way forward. And when I asked why self-advocacy had not taken off, he invoked parental paternalism: in Uganda, the director explained, people with cognitive disabilities were cossetted and oppressed by their parents, kept at home, and prevented from speaking on their own behalf and pursuing their own wishes. Leaders of Uganda's national disability associations and NGOs widely espouse this vision of suffocating parental paternalism. When I expressed doubts that self-representation was a tenable goal for all people with dis- 
abilities, especially those who did not speak, a leading activist who heads the East African disability office of a transnational development agency appealed to assistive technology and the spirit of technological optimism: he said that there was equipment available in North America and Europe that enabled people without language to communicate their needs and desires, and that if such equipment were only made available in Uganda, even disabled Ugandans who could not speak would be able to represent themselves.

Against this backdrop, Florence's assertion that "children are persons too" underlines the disappearance of a certain segment of disabled people underwritten by liberal ideas of self-representation working in tandem with normative expectations about what constitutes the capacity to represent oneself. Florence's assertion also made an appeal to other terms of personhood beyond self-representation, though she did not spell out those terms exactly. But a closer look at the Ugandan Christian organizations that focus on cognitive disability makes such terms clear.

\section{THE SENSE OF CHILDHOOD}

All the leaders of disability organizations taking part in the debate at NUDIPU spoke of children with disabilities and people with cognitive disabilities in the same breath: those "children" who are "persons too," as the director of SCT put it. Maimuna likewise spoke of the residents of L'Arche, to some extent distancing herself, as a helper, from that category but nonetheless reinforcing it as the relevant frame for residents at L'Arche. All the residents and students of programs like L'Arche and SCT are referred to as children (abaana) by staff, parents, neighbors, and supporters. Yet such "children" range considerably in age, from toddlers to adults in late middle age. All such organizations have participants in their twenties and thirties, while older organizations like L'Arche and SCT have "children" who are in their forties. Conversations with caregivers revealed that not much reflection is given to why disabled adults in their forties were considered children; it seemed simply obvious. For these caregivers, then, the status of child is less tied to biological age than to perceived limitations in cognitive capacity and social competence, as well as to corresponding forms of dependency.

Infantilization constitutes a central concern within Euro-American disability activism, which objects to the paternalistic treatment of adult disabled peoplewithout full autonomy, in need of care and custodianship — on the basis of physical or cognitive impairments. This critique assumes that childhood is not full personhood. Yet things may not prove so simple in the case at hand. Childhood extends a category of personhood that, in Uganda, is both readily meaningful and socially 
available to people with cognitive disabilities. It is not through self-representation, as articulate and autonomous subjects, that Ugandan Christian organizations make people with cognitive disabilities appear. Instead, by figuring disabled people as children, groups like L'Arche and SCT define them as persons who deserve care and support and, more fundamentally, as persons in the first instance.

A kind of lived paternalism defines the activities at L'Arche and SCT. It manifests in the aesthetics of everyday life in these settings, or what life looks and feels like, starting with classroom routines and disciplines, dormitory-style sleeping arrangements, and hierarchal distributions of authority and care. This making of disabled personhood-as-childhood extends to the most intimate of terms: people with cognitive disabilities become visible as children beginning with the surface of their bodies. The school uniform is one of the central material forms for making this happen: All the "children" wear school uniforms, modeled after the apparel of Ugandan schoolchildren. For girls, this consists of either a knee-length dress or a shirt or blouse with a knee-length skirt; for boys, it is a shirt and a pair of shorts. Biological age once more does not matter when it comes to who wears these uniforms; they are worn even by the oldest disabled members of L'Arche and SCT in their thirties and forties. Like all Ugandan schoolchildren, people with cognitive

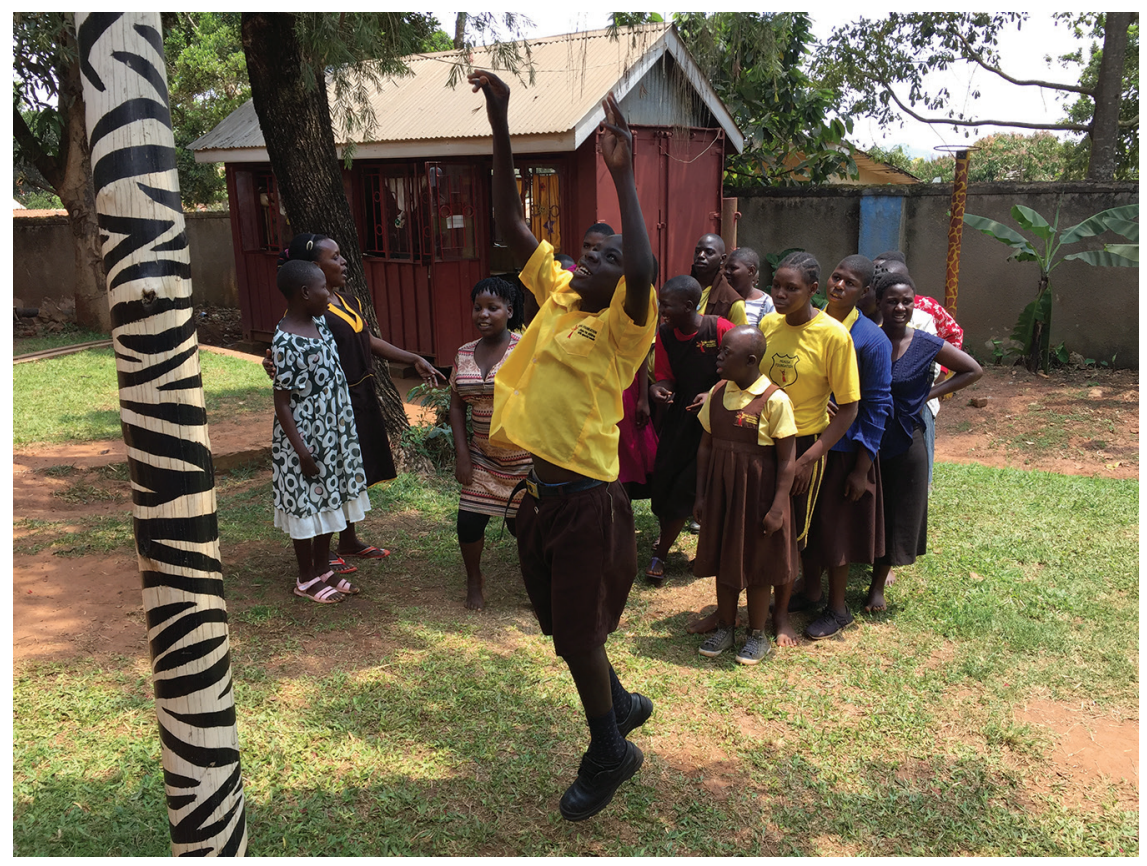

Figure 2. SCT students line up to shoot basketball. Photo by Tyler Zoanni. 
disabilities participating in Christian institutions wear uniforms for everyday activities, like classes, community outings, and recreation.

Hair is a second medium through which the childhood of people with cognitive disabilities is made apparent. The "social distribution of long and short hair" (Turner 1980, 117) is not rigidly fixed in Uganda, but it does have some broad contours. Shaved heads are the norm for both boys and girls. In part, this is hygienic, as it helps control parasites like lice. In part, this derives from economic reasons, as braids and hair work are expensive. And, finally, it is in part due to comfort, as hair may prove heavy and hot. In contemporary Kampala, longer hair, especially if styled or braided, serves adults and especially women as a means of social distinction and aesthetic cultivation. In this way, having longer hair is often a privilege if not a requirement of adulthood, while shaved hair functions as an obligatory mark of childhood. At L'Arche and SCT, relatively few of the female staff members have shaved heads, though it is more common for men. In contrast, all the disabled men and nearly all the disabled women had shaved heads.

"Children" in these contexts react to their status as children in various ways. Nonreaction is perhaps most common. Many people at L'Arche and SCT do not speak, and the majority of those who do speak do not appear to give the term much reflection. They are too busy playing, learning, and making messes to have much time for reflection on social categories or the politics of personhood. But a few have stronger reactions. Consider the examples of Lamula and Prossie, both of whom participate in L’Arche programs.

Lamula has a kind of honorary status as one of the founding members of LArche. She was one of its first two residents and the source of the name of one of its two houses, Lamula House. Lamula's exact age is unknown, but L'Arche staff members guess she is in her forties; her hair has turned completely gray. Lamula, however, insists she is a "child," chiefly as a corrective to anyone who suggests otherwise, and she does so with much vehemence. This happens most often when someone greets Lamula in passing with the Luganda honorific nnyabo, a term roughly equivalent to madam or ma'am, and which for reasons of politeness is generally used in both casual and formal interactions. So routinized are invocations of nnyabo that even caregivers who have known Lamula for years slip up; it is all the more common for visitors or the hapless anthropologist to do so. Addressing Lamula as nnyabo prompts a torrent of complaints on her part. She insists that she is not nnyabo but a child, and she enrolls anyone in earshot as a witness to the injustice of anything said to the contrary. Several caregivers at L'Arche find this funny, and they tease Lamula on this front, calling her a woman (omukyala or omukazi), much 
to her chagrin. Lamula, in response, is always tenacious in claiming her childhood status, and her increasingly urgent and distraught insistence typically drives even amused bystanders to join in collective efforts to make amends for the mistake and to assure her that they know she is a child.

In contrast to Lamula, Prossie is certain she is not a child. Prossie is a single mother in her thirties who had been hired at L'Arche after have having been a resident there for a couple of years. She was first brought to live in L'Arche by a family friend but was soon promoted to the role of a paid staff member when it became clear that she needed little in the way of supervision to engage in cleaning, cooking, or crafts making. Today Prossie rents a one-room house not far from L'Arche, and she lives there with her son. The director of L'Arche told me that she considered Prossie to be one of the organization's success stories. Prossie had, after all, transitioned from being in the category of cared-for to being a caregiver, even as she was herself disabled. Staff members at L'Arche knew that Prossie had a diagnosis of Down syndrome — she had received such a diagnosis when she first came to L'Arche - and they tended to talk about her as one of the "children." That is, when they talked about her, it was as one among the many disabled people who lived at L'Arche. Yet in our conversations, Prossie adamantly insisted that she was not one of the "children." She pointedly distanced herself from "them," thus putting herself in a distinct person class. In talking about her relationships with other people at L'Arche, Prossie aligns herself exclusively with other staff members; she singles out several staff members as particular friends, while professing that she does not feel as close to any of the "children" for whom she cares.

Prossie thus resisted being a "child." Although many L'Arche staff members still considered her one as a result of her disability, Prossie had to some extent transcended childhood by virtue of gainful employment, renting a house, and having a child. Lamula, meanwhile, fully embraced her status as a child and fervently resisted even conversational rituals that positioned her as woman. Lamula and Prossie mark the two outer poles on a continuum of reactions from people with cognitive disabilities at places like L'Arche and SCT; it is a continuum ranging from total identification to rejection. Yet in spite of their differences, Prossie and Lamula shared having their personhood defined in terms of childhood, which served as the baseline against which they negotiated their own self-understandings and social relations. 


\section{DIVINE IMAGES}

If disabled residents and students at LAArche and SCT are "children," then they are also "children of God." This is a common trope throughout the New Testament (e.g., John 1:12; Gal. 3:26, 2 Cor. 6:18), and one espoused by staff members at L'Arche and SCT. These staff members consider as a particularly important story a moment in the Gospels when Jesus calls for "the little children" to be brought to him (Matt. 19:13-15; Mk. 10:13-16; Lk. 18:15-17). This story inspired the popular Christian song "Jesus Loves the Little Children," which I sang more times than I care to recount during my fieldwork. The idea behind this song's deployment, as well as behind the imagery of children of God, is that the disabled "children" at L'Arche and SCT are precious in the eyes of God, just like all other children.

A second theological trope I heard at L'Arche and SCT is the claim that people with disabilities are created in the "image of God," a notion derived from Genesis 1:26, which portrays God as creating humanity in a way that bears a likeness to the divine. Ugandan Christian efforts focusing on disability use the notion of the image of God to argue for the basic dignity and value of the lives of people with disabilities - asserting that they, too, partake in likeness to the divine, and as such deserve respect and engagement. Both the image-of-God and the children-ofGod tropes appeal to a shared personhood grounded in biblical imagery.

This repertoire of Christian imagery provides a charter for a nonsecular politics of disability. The imagery gives meaning and value to those whose personhood is questioned within a social context in which Christianity is broadly hegemonic. Such imagery comes into the foreground at places like L'Arche and SCT primarily in these organizations' efforts to address broader publics. That is, this Christian imagery is not constantly invoked in everyday work at L'Arche and SCT as people go about activities like caregiving, teaching, and other efforts that manifest people with cognitive disabilities as children. Instead, these theological tropes explicitly emerge during these organizations' public events, when people visit them for the first time, and in trainings for new employees or volunteers.

Along these lines, L'Arche and SCT work to make cognitively disabled people appear not only within their immediate institutional settings but also within broader religious and social settings. At the same time, these organizations' different forms of Christianity — Catholic and Pentecostal — lead to different forms of appearance. While L'Arche and SCT both engage in the work of assembling disabled people together, such that they appear publicly in visible and audible fashion, the scale and horizons of disability appearance differ, in ways that reflect distinct Christian traditions. 
At L'Arche, the Catholic institution, the mode of wider disability appearance can be described as one of incarnation, an assembling of people in tangible proximity. L'Arche itself forms part of a transnational network of homes for people with cognitive disabilities that have roots in Thomistic strands of Catholic theology emphasizing values of friendship and life together (e.g., Reinders 2010). These values are readily evident in the quality and organization of everyday life at L'Arche in Uganda. A great deal of time at L'Arche each day involves nondirective collectivity. Every afternoon, after the dishes are washed and the dining room and kitchen are cleaned up, many people, whether disabled or nondisabled, assemble on the benches that line the porches of the main compound's house. There they listen to the radio, gossip, joke, or just sit quietly. Days begin, end, and are punctuated by joining together for meals, prayers, and leisure. In part, this structure has task-specific purposes, but it also reflects the value of togetherness as an end in itself.

This assembling of bodies together — what I am calling appearance as incarnation - also becomes evident in the activities that most incorporate people who are not L'Arche members and that bring L'Arche residents into public settingsnamely, church activities. Here, for example, is Maimuna again, singing with the choir of the parish Catholic church on Palm Sunday, before the church's Mass.

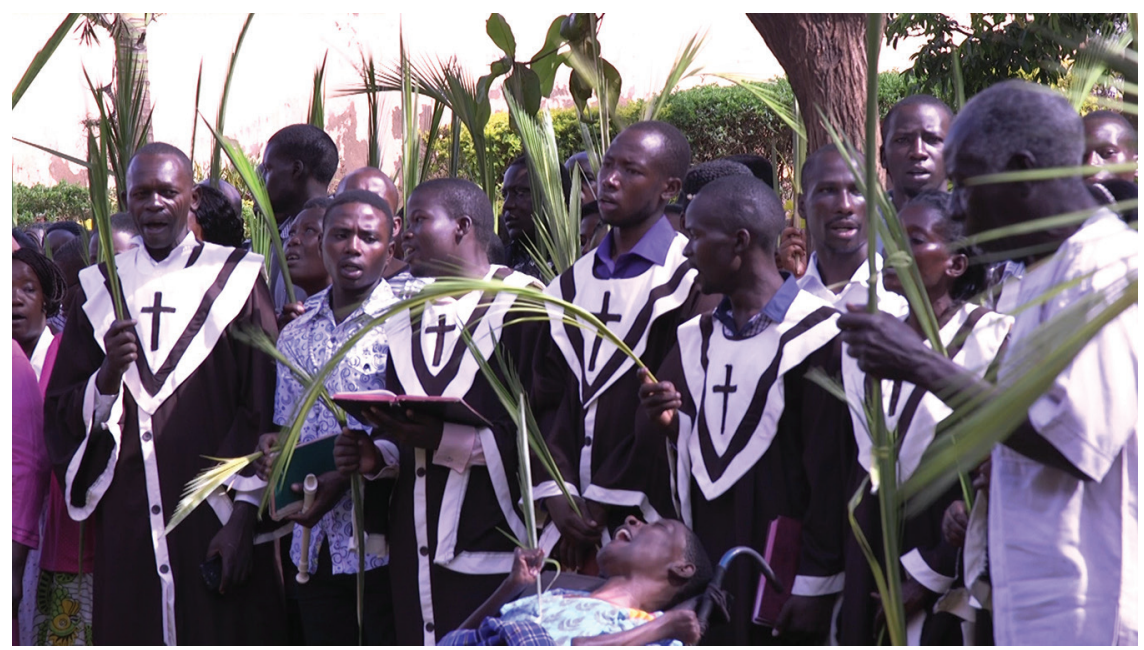

Figure 3. Maimuna sings with a Palm Sunday choir. Photo by Tyler Zoanni.

The procession of the palms began at L'Arche, with the home's residents processing at the front. Maimuna was singing as she loves to do, in this case a Catholic hymn. Although she identifies as a Muslim, she will gladly sing anything and frequently performs at L'Arche gatherings. After the priest called the procession to 
order, Maimuna was wheeled, and others walked, to the nearby Catholic church through the dusty backroads of the sleepy neighborhood on the outskirts of Kampala where L'Arche is located. The horizon of this assembly of bodies that emerged into public was ultimately that church, where the Palm Sunday service occurred. This gathering represented a joining together of disabled and nondisabled people that folded them into a public Catholic ritual, as disabled and nondisabled members of L'Arche sat on the pews where they could find space among the members of the church.

We see a very different form of disability appearance with SCT, the Pentecostal school. There we find an emphasis on revelation, or forms of visual display that aspire to the widespread and at times reach the level of the spectacular. As Birgit Meyer (2011, 2015) has observed of Ghana, Pentecostal projects often aim to erupt into public life, exercising influence even on people and social arenas that do not become Pentecostal. The aspiration to attain widespread publicity is evident in the many forms of outreach central to SCT's efforts, including meetings with government officials and organizations like NUDIPU, public presentations on disability topics, an extremely avid use of social media, the director Florence's frequent appearances on radio and television, and most of all the annual "Special Needs Awareness Day." This event involves more than a thousand people and draws dignitaries such as leading politicians and rulers of the kingdoms in Uganda.

I participated in several of these Awareness Days throughout the years. They all began with a long march to the event venue, a major stadium in central Kampala. Here I pull screenshots from SCT's Facebook page to underline the efforts at

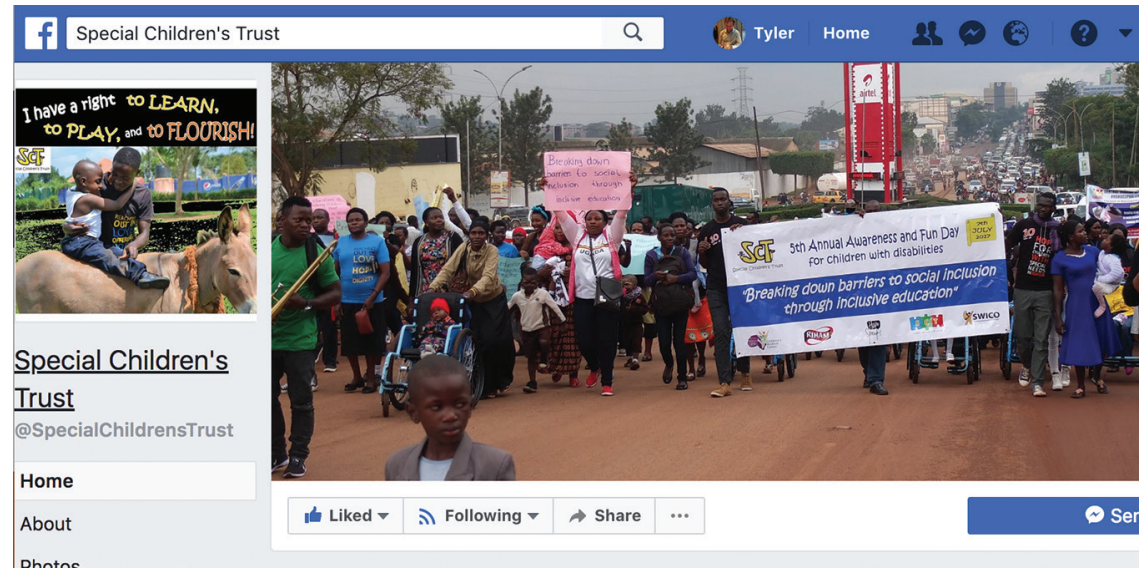

Figure 4. SCT's Facebook page prominently features a scene of the Awareness Day March. Screenshot by Tyler Zoanni. 
amplifying the public nature of such efforts across multiple media - on the street during the event itself and then again on social media long after that.

This march occurs on Jinja Road, one of the busiest in Kampala and indeed in all of Uganda: it is the feeder road that connects Kampala to all of eastern Uganda and is a major hub for buses, trucks, cargo containers, and taxi vans. SCT secures police and government support to shut down the road for the roughly hour-long march, and it draws a variety of television stations filming the event.

The march then culminates in a stadium assembly. A variety of organizations that work with people with cognitive disabilities give dances, songs, and other performances, highlighting what they do. The rhetoric scaffolding these performances is highly sentimentalizing and emphasizes both the shared humanity and particular qualities of individual "children" before the gathered audience of disability organizations, the Ugandan press, and dignitaries from the national government and Uganda's kingdoms.

In this way, even as both L'Arche and SCT share a stock of common Christian imagery, they pursue different modes of disability appearance, with distinct articulations of the place of disabled people in wider social life. Pursuing what I have called incarnation, the Catholic organization L'Arche puts a premium on assembling bodies together and folding them into church life. The forms of publicity L'Arche pursues arc toward Catholic settings and do not seek a larger scale than that of the neighborhood where the organization is located. Placing a greater emphasis on what I called revelation, the Pentecostal organization SCT emphasizes urban spectacle, making the center of its year an annual event widely visible in downtown Kampala. A centrifugal quality defines this mode of disability appearance, as it spreads broadly in the capital city's core and draws countless drivers and passengers who are stopped by the march, as well as the national media who cover the event.

\section{CONCLUSION}

As I have shown, a liberal politics of disability promotes a logic of self-representation that serves to erase the issues facing people with cognitive disabilities in Uganda, while negating their social and political standing as persons. In contrast, it is within the relatively small network of Christian institutions that people with cognitive disabilities appear, doing so as children in paternalistic religious contexts as well as wider collective settings.

So what? Why, one might wonder, does processing to a church or even holding a rally matter? If it is clear that such efforts are neither secular nor liberal, as 
I have claimed, is this really the basis of a nonsecular and nonliberal politics of disability? Is politics a meaningful word here?

I opened by invoking Arendt's vision of the basis of politics in appearance. I noted that while Arendt's approach may prove counterintuitive in light of prevailing Western metaphysical assumptions, it is in fact highly obvious to people in Uganda. Arendt's concern with appearances has thus served to help me name and describe key dynamics of Ganda social aesthetics, in which display proves central to the ratification and evaluation of proper forms of being a person. The terrain of appearances, as I have shown, constitutes a highly fraught arena for cognitively disabled Ugandans, but it remains crucial for the assertion of their status as persons.

It bears noting, however, that in other ways Arendt's thinking about appearances makes for a highly infelicitous resource for discussing the lives and worlds of people like Maimuna, with whose desire to be photographed I opened. That is because Maimuna depends, in a conventional sense, on the assistance of others to meet her needs. For Arendt, living such a life of dependence undermines one's capacity for appearing in public and for engaging in meaningful political action. Arendt not only describes but seemingly endorses a classical Greek distinction between the oikos, or home, as a realm of slaves, women, children, the infirm, and the elderly engaging in meeting basic bodily needs, and the polis, or city, as the realm of a minority of free men who appear to one another and thus engage in politics (Arendt 1998, 24-28, 192-207).

Others have interrogated Arendt's "Hellenism" (Euben 2000) and rightly pointed out that this account of appearances is not only highly gendered but sexist as well as elitist (see Honig 1995). Here, I join the recent readers of Arendt with whom I opened, who demonstrate that her basic framework for thinking about politics is more capacious than the specific account she develops in line with Hellenistic social norms. Butler (2015), for example, challenges criticisms that movements like Occupy Wall Street and Black Lives Matter do not constitute serious political movements insofar as they do not articulate a concrete list of political demands. Butler (2015, 25-26) argues that simply to appear in public enacts a "call for justice":

even when they are not speaking or do not present a set of negotiable demands, the call for justice is being enacted: the bodies assembled "say" "we are not disposable," whether or not they are using words at the moment; what they say, as it were, is "we are still here, persisting, demanding greater justice, a release from precarity, a possibility of a livable life." 
Likewise, Jacques Rancière (1999, 9, 21-42) asserts that politics only happens when "whoever has no part" in a common order contentiously irrupts into public life and thus rearranges the "partition of the perceptible." This definition of the political is explicitly opposed to more conventional definitions that stress the bureaucratized procedures of representational politics.

Butler explicitly and Rancière implicitly oppose their accounts to Arendt's, but they do so by relying on Arendt's emphasis on appearances. I, too, have relied on such an emphasis. This is not to say that appearance is inherently redemptive, whether for disabled Ugandans or in general. After all, ableism, or antidisability discrimination, operates like racism insofar as it fixates on and targets the appearance of non-normative bodies. But it is to say that appearances can do important work, and that it proves meaningful to understand this work as political. Across everyday life as "children" and through what I have called Pentecostal revelation and Catholic incarnation, people with cognitive disabilities appear by virtue of Christian efforts, and such manifestations challenge the fact that they otherwise rarely appear in collective life in Uganda.

Let me be clear. By pointing to what is foreclosed by a seemingly salutary liberal set of ideas and what is made possible by seemingly repugnant paternalistic ones, my aim is not simply to condemn the former and celebrate the latter. Instead, I have explored an instance in which "'human rights talk' . . can marginalize other ways of conceiving of human dignity and value," as Harri Englund (2000, 580) has put it. For transnational disability discourses, such as those enshrined in the United Nations Convention on the Rights of Persons with Disabilities, the project of human dignity is tied inextricably to notions of self-representation and autonomy, which are themselves understood as self-evident rights. Against such unexamined self-evidence, this article suggests there may be more than a little daylight between dignity and value, on the one hand, and self-representation and autonomy, on the other. In the case this article examines, the dignity, value, and indeed the mere appearance of cognitively disabled Ugandans depend not on self-representation but on forms of personhood that unfold as childhood.

Moreover, a stringent insistence on ideas like self-representation and autonomy may militate against the achievement of dignity, especially in cases where profound dependency forms a constitutive condition of people's lives. This idea evokes important recent discussions of the ways in which people in sub-Saharan Africa cultivate relations of hierarchy and dependency as vehicles for social and economic possibility, means of securing and sustaining life in circumstances of relative deprivation, where the state cannot be counted on to provide support 
(Whyte et al. 2013; Scherz 2014; Ferguson 2015; Haynes and Hickel 2016; Haynes 2017). Cognitive disability necessarily intersects with, and underlines, such forms of socioeconomic dependency, especially in cases of impairments that leave people unable to meet their basic needs, in part or in full, by themselves. In contrast, a liberal politics of disability presumes, celebrates, and works to realize a very different picture of the person - articulate, educated, independent, and capable of activism and self-representation as well as self-sufficiency. The "children" who live in and attend places like L'Arche and SCT are unlikely to ever realize such a picture of the person. One need not endorse or subscribe to the Christian paternalism at places like L'Arche and SCT to notice what it does in making people with cognitive disabilities appear - people, that is, who might not otherwise appear at all.

\begin{abstract}
This article considers how Christianity contributes to the appearance of cognitive disability in Uganda, a country with some of the most progressive disability policies in the world but little in the way of formal care and advocacy for cognitively disabled people. As a point of departure, the article invokes Hannah Arendt's notion of appearance as a way to thematize the importance of public display in Ugandan social life, as well as the challenge that people with evidently profound disabilities pose to Ugandan social aesthetics. It first traces how cognitive disability disappears under the liberal logics that organize Uganda's secular disability laws and activism, and then compares the ways that Catholic and Pentecostal efforts sustain the appearance of cognitive disability, in light of their theological differences and their common paternalism. Even as Christian paternalism in the face of cognitive disability may prove repugnant to a liberal vision of disability politics, I argue that it sustains a form of disability appearance otherwise not possible in Uganda. [cognitive disability; religion; social aesthetics; liberalism; personhood; Uganda]
\end{abstract}

\title{
BUFUNZE
}

Ekiwandiiko kino kilagira ddala bulungi, nga obukristaayo bwe bwewaddeyo ennyo ku nsonga etekwatiddwa bulungi ey'endabika y'abantu abalina obulemu mu butesobola nga buva ku bwongo nga bali mu Uganda. Eggwanga erya Uganda lirina enkola ennungi mu byokwezza obuggya ku nsonga y'abantu abo munsi yonna. Wabula ate kinakuwaza nnyo, nti libulamu nnyo enkola ennungamu mu ngeri y'okuwagira endabirira esaanidde abantu abo, mu mbeera zaabwe zonna okutwalira awamu. Ekiwandiiko kino okwawukana ku bya bulijjo ebirala byonna, kikoona butereevu ku ndowooza ya Hannah Arendt, era nga kirina n'okulaga okusomooza okuleteddwaawo obutafa bulungi ku bantu abo mu mbeera zaabwe mu ggwanga lyonna. Ekiwandiiko kisookera ddala n'okulaga engeri y'okufaayo ku nsonga eyo bwe kigenda kisaanirawo ddala nga kino kiyita mu kwekkiriranya abantu kwe batambuliramu ng'abakweyam- 
bisa, nga bakola amateeka agakwata ku butesobola obw'obwongo, wamu nebirala ebikolebwa okukisaamu amaanyi, Kati ekyo, nga bwe twongerako netukigeerageeranya n'ekyo ekikolebwa abakatuliki n'aba Pentekooti ku nsonga eyo yemu mu kuyimirizaawo endabika entuufu eyandisaanidde ku bantu abo abalina obulemu bwobutesobola. Naye ate olwokuberawo enjawukana z'e byeddini wakati waabo bombi, nekitasobola kutambula bulungi, nga kino kiva mu kugaaana okukolera awamu nga abantu abali ku mulimu ogumu. Ekisinga obukulu nga kyekireeeta obutakkanya obwo kyangu okulaba. Kale obutasobola kukolera wamu olw'obukulu bwensonga eyo, nakyo kiyinza okuva ku bukyaayi okwesigamiziddwa ku kwolesebwa okulina obulemu mu bwongo, mu nfuga yaabwo egobererwa. Ekyo ne kiyimirizaawo endabika eyobulemu obutesobola era nga nayo tesoboka mu Uganda kukolebwako. [Obulemu mu bwongo, eddiini, obulabika, nampawengwa, obuntu, Uganda]

\section{NOTES}

Acknowledgments My first debt is to the people discussed in this article, most of whom I regrettably cannot name except by way of pseudonyms here. For conversations and other forms of assistance that have taught me much about disability in Uganda, I am grateful to Rose Yooumbe, Boas Muhumza, and Florence Namaganda. The article has benefited from the questions, criticisms, and suggestions of Catherine Abbo, Abena Asare, Pamela Block, Sandra Calkins, Lindsay Ehrisman, Matthew Engelke, Michele Friedner, Faye Ginsburg, Naomi Haynes, Cassandra Hartblay, Fred Klaits, Julie Livingston, George Mpanga, Patrick Ojok, Elayne Oliphant, Stephanie Palazzo, Rayna Rapp, Christine Sargent, China Scherz, Bambi Schieffelin, Angela Zito, three anonymous reviewers, and the editorial collective for Cultural Anthropology, as well as audiences at the University of Bayreuth, Columbia University, the University of Chicago, Cumberland Lodge, and Stony Brook University. The research and writing for this article were enabled by the generosity of the Mellon/ACLS Dissertation Completion Fellowship, the Social Science Research Council, the Wenner-Gren Foundation, New York University, the National Science Foundation, and the Lemelson Foundation/Society for Psychological Anthropology.

1. This article draws on twenty-four months of research, the bulk of which was thirteen months spanning 2016 and 2017. My fieldwork ranged widely across Ugandan family life, secular NGOs, and government offices, but its focus was intensive participant observation in two Christian institutions, which form the core of this article.

2. Both intellectual disability and cognitive disability are commonly used terms. Following the philosophers Licia Carlson and Eva Feder Kittay (2010), I use cognitive disability, with the premise being that cognition denotes not only the intellect but also domains like emotion and perception and thus names a broader matrix of difference. That said, here I am less concerned with diagnostic specificities or naturalizing disability categories than I am with the social and political life of cognitive disability as a frame for human difference.

3. There is evidence of a long history to this configuration of space. The historian Holly Hanson (2009) analyzes maps of Buganda's precolonial capital in terms of the relationships among palaces; those maps that contain the detail of individual palaces depict large areas of open space.

4. A small cluster of ethnographic and historical studies suggests that this emphasis on appearances is not restricted to Buganda. It is discernible in both political practice and everyday life in the wider Great Lakes region (e.g., Beattie 1971, 106-10, 138-41; Weiss 1996, 119-25, 2003, 26-39) and beyond (e.g., Archambault 2017, 43-71; Haynes 2017, 37-56). 


\section{REFERENCES}

Abimanyi-Ochom, Julie, and Hasheem Mannan

2014 "Uganda's Disability Journey: Progress and Challenges." African Journal of Disability

Adams, Rachel 3, no. 1. https://doi.org/10.4102/ajod.v3i1.108.

2001 Sideshow U.S.A.: Freaks and the American Cultural Imagination. Chicago: University of Chicago Press.

Archambault, Julie Soleil

2017 Mobile Secrets: Youth, Intimacy, and the Politics of Pretense in Mozambique. Chicago: University of Chicago Press.

Arendt, Hannah

1981 The Life of the Mind, Volumes 1 and 2. San Diego, Calif.: Harcourt. Originally published in 1977 and 1978.

1998 The Human Condition. 2nd ed. Chicago: University of Chicago Press. Originally published in 1958.

Barker, Clare, and Stuart Murray

2013 "Disabling Postcolonialism: Global Disabilty Cultures and Democratic Criticism." In The Disability Studies Reader, 4th edition, edited by Lennard J. Davis, 61-73. New York: Routledge.

Beattie, John

1971 The Nyoro State. Oxford: Clarendon.

Bogdan, Robert

1988 Freak Show: Presenting Human Oddities for Amusement and Profit. Chicago: University of Chicago Press.

Boyd, Lydia

2013 "The Problem with Freedom: Homosexuality and Human Rights in Uganda." Anthropological Quarterly 86, no. 3: 697-724. https://doi.org/10.1353/

Brenneis, Donald anq.2013.0034.

1987 "Performing Passions: Aesthetics and Politics in an Occasionally Egalitarian Community." American Ethnologist 14, no. 2: 236-50. https://doi.org/10.1525/

Butler, Judith ae.1987.14.2.02a00040.

2015 Notes Toward a Performative Theory of Assembly. Cambridge, Mass.: Harvard University Press.

Carlson, Licia, and Eva Feder Kittay

2010 "Introduction: Rethinking Philosophical Presumptions in Light of Cognitive Diasbility.” In Cognitive Disability and Its Challenge to Moral Philosophy, edited by Eva Feder Kittay and Licia Carlson, 1-25. Malden, Mass.: Wiley-Blackwell.

Comaroff, John L., and Jean Comaroff

2001 "On Personhood: An Anthropological Perspective from Africa." Social Identities 7, no. 2: 267-83. https://doi.org/10.1080/13504630120065310.

Das, Veena, and Renu Addlakha

2001 "Disability and Domestic Citizenship: Voice, Gender, and the Making of the Subject.” Public Culture 13, no. 3: 511-32. https://doi.org/10.1215/08992363-133-511.

Devlieger, Clara

2018 "Rome and the Romains: Laughter on the Border between Kinshasa and Brazzaville."

Elisha, Omri Africa 88, no. 1: 160-82. https://doi.org/10.1017/S0001972017000614.

2008 "Moral Ambitions of Grace: The Paradox of Compassion and Accountability in Evangelical Faith-Based Activism." Cultural Anthropology 23, no. 1: 154-89. https://doi.org/10.1111/j.1548-1360.2008.00006.x. 
Englund, Harri

2000 "The Dead Hand of Human Rights: Contrasting Christianities in Post-Transition Malawi." Journal of Modern African Studies 38, no. 4: 579-603. https://www.jstor.

Euben, J. Peter org/stable/161510.

2000 “Arendt's Hellenism.” In The Cambridge Companion to Hannah Arendt, edited by Ferguson, James Dana Villa, 151-64. New York: Cambridge University Press.

2015 Give a Man a Fish: Reflections on the New Politics of Distribution. Durham, N.C.: Duke

Friedner, Michele University Press.

2015 Valuing Deaf Worlds in Urban India. New Brunswick, N.J.: Rutgers University Press.

2017 "How the Disabled Body Unites the National Body: Disability as 'Feel Good' Diversity in Urban India." Contemporary South Asia 25, no. 4: 347-63. https://doi. org/10.1080/09584935.2017.1374925.

2018 "Vessel of God/Access to God: American Sign Language Interpreting in American Evangelical Churches.” American Anthropologist 120, no. 4: 659-70. https://doi. org/10.1111/aman.13117.

Friedner, Michele, and Tyler Zoanni

2018 "Disability from the South: Toward a Lexicon." Somatosphere, December 17. http://somatosphere.net/2018/12/disability-from-the-south-toward-a-lexicon. html.

Garland-Thomson, Rosemarie

1997 Extraordinary Bodies: Figuring Physical Disability in American Culture and Literature. New York: Columbia University Press.

2009 Staring: How We Look. New York: Oxford University Press.

Ginsburg, Faye

2012 "Disability in the Digital Age." In Digital Anthropology, edited by Heather A. Horst and Daniel Miller, 101-126. New York: Berg.

Ginsburg, Faye, and Rayna Rapp

2013 "Disability Worlds." Annual Review of Anthropology 42: 53-68. https://doi.org/10. 1146/annurev-anthro-092412-155502.

Grech, Shaun, and Karen Soldatic, eds.

2016 Disability in the Global South: The Critical Handbook. Cham, Switzerland: Springer.

Grinker, Roy Richard

2007 Unstrange Minds: Remapping the World of Autism. New York: Basic Books.

Hanson, Holly

2009 "Mapping Conflict: Heterarchy and Accountability in the Ancient Capital of Buganda." Journal of African History 50, no. 2: 179-202. https://doi.org/10.1017/ S0021853709990065.

Hartblay, Cassandra

2017 "Good Ramps, Bad Ramps: Centralized Design Standards and Disability Access in Urban Russian Infrastructure.” American Ethnologist 44, no. 1: 9-22. https://doi.

Hattersley, Charles W. org/10.1111/amet.12422.

1908 The Baganda at Home, with One Hundred Pictures of Life and Work in Uganda. London:

Haynes, Naomi Religious Tract Society.

2017 Moving by the Spirit: Pentecostal Social Life on the Zambian Copperbelt. Oakland: University of California Press.

Haynes, Naomi, and Jason Hickel

2016 "Introduction: Hierarchy, Value, and the Value of Hierarchy." Social Analysis 60, no. 4: 1-20. https://doi.org/10.3167/sa.2016.600401. 
Honig, Bonnie, ed.

1995 Feminist Interpretations of Hannah Arendt. University Park: Penn State University Press.

Kasnitz, Devva, and Russell P. Shuttleworth

2001 "Introduction: Anthropology in Disability Studies." Disability Studies Quarterly 21,

Kodesh, Neil no. 3: 2-17. http://dsq-sds.org/article/view/289/327_2.

2001 "Renovating Tradition: The Discourse of Succession in Colonial Buganda." International Journal of African Historical Studies 34, no. 3: 511-41. https://doi.

Kohrman, Matthew org/10.2307/3097552.

2005 Bodies of Difference: Experiences of Disability and Institutional Advocacy in the Making of Modern China. Berkeley: University of California Press.

Kulick, Don, and Jens Rydström

2015 Loneliness and Its Opposite: Sex, Disability, and the Ethics of Engagement. Durham, N.C.: Duke University Press.

Landsman, Gail Heidi

2009 Reconstructing Motherhood and Disability in the Age of "Perfect" Babies. New York: Routledge.

Livingston, Julie

2006 "Insights from an African History of Disability." Radical History Review 2006, no. 94: 111-26. https://doi.org/10.1215/01636545-2006-94-111.

2008 "Disgust, Bodily Aesthetics, and the Ethic of Being Human in Botswana." Africa 78, no. 2: 288-307. https://doi.org/10.1353/afr.0.0002.

MacDougall, David

1999 "Social Aesthetics and the Doon School." Visual Anthropology Review 15, no. 1: 3-20. https://doi.org/10.1525/var.1999.15.1.3.

McKearney, Patrick

2017 "L'Arche, Learning Disability, and Domestic Citizenship: Dependent Political Belonging in a Contemporary British City." City and Society 29, no. 2: 260-80. https://doi.org/10.1111/ciso.12126.

McKearney, Patrick, and Tyler Zoanni

2018 "Introduction: For an Anthropology of Cognitive Disability." Cambridge Journal of Anthropology 36, no. 1: 1-22. https://doi.org/10.3167/cja.2018.360102.

Meyer, Birgit

2011 "Going and Making Public Pentecostalism as Public Religion in Ghana." In Christianity and Public Culture in Africa, edited by Harri Englund, 149-66. Athens: Ohio University Press.

2015 Sensational Movies: Video, Vision, and Christianity in Ghana. Berkeley: University of California Press.

Nakamura, Karen

2006 Deaf in Japan: Signing and the Politics of Identity. Ithaca, N.Y.: Cornell University Press.

Nancy, Jean-Luc

2000 Being Singular Plural. Translated by Robert D. Richardson and Anne E. O'Byrne. Stanford, Calif.: Stanford University Press. Originally published in 1996.

Ochs, Elinor, and Olga Solomon

2010 "Autistic Sociality." Ethos 38, no. 1: 69-92. https://doi.org/10.1111/j.15481352.2009.01082.x.

Peterson, Derek R.

2012 Ethnic Patriotism and the East African Revival: A History of Dissent, c. 1935-1972. New

Phillips, Sarah D. York: Cambridge University Press.

2011 Disability and Mobile Citizenship in Postsocialist Ukraine. Bloomington: Indiana University Press. 
Povinelli, Elizabeth A.

2002 The Cunning of Recognition: Indigenous Alterities and the Making of Australian Multiculturalism. Durham, N.C.: Duke University Press.

Ralph, Laurence

2012 "What Wounds Enable: The Politics of Disability and Violence in Chicago." Disability Studies Quarterly 32, no. 3. https://doi.org/10.18061/dsq.v32i3.3270.

Rancière, Jacques

1999 Disagreement: Politics and Philosophy. Translated by Julie Rose. Minneapolis: University of Minnesota Press.

Rapp, Rayna, and Faye Ginsburg

2001 "Enabling Disability: Rewriting Kinship, Reimagining Citizenship." Public Culture 13, no. 3: 533-56. https://doi.org/10.1215/08992363-13-3-533.

2007 "Enlarging Reproduction, Screening Disability." In Reproductive Disruptions: Gender, Technology, and Biopolitics in the New Millennium, edited by Marcia C. Inhorn, 98-121. New York: Berghahn.

2011 "Reverberations: Disability and the New Kinship Imaginary." Anthropological Quarterly 84, no. 2: 379-410. https://doi.org/10.1353/anq.2011.0030.

Reinders, Hans S., ed.

2010 The Paradox of Disability: Responses to Jean Vanier and L'Arche Communities from Theology and the Sciences. Grand Rapids, Mich.: Eerdmans.

Richards, Audrey I.

1964a “Authority Patterns in Traditional Buganda." In The King's Men: Leadership and Status in Buganda on the Eve of Independence, edited by L. A. Fallers, 256-93. London: Oxford University Press.

1964b “Traditional Values and Current Political Behavior." In The King's Men: Leadership and Status in Buganda on the Eve of Independence, edited by L. A. Fallers, 294-335. London: Oxford University Press.

Robbins, Joel, Bambi B. Schieffelin, and Aparecida Vilaça

2014 "Evangelical Conversion and the Transformation of the Self in Amazonia and Melanesia: Christianity and the Revival of Anthropological Comparison." Comparative Studies in Society and History 56, no. 3: 559-90. https://doi.org/10.1017/ S0010417514000255.

Scherz, China

2014 Having People, Having Heart: Charity, Sustainable Development, and Problems of Dependence in Central Uganda. Chicago: University of Chicago Press.

Schweik, Susan M.

2010 The Ugly Laws: Disability in Public. New York: New York University Press.

Seel, Martin

2005 Aesthetics of Appearing. Translated by John Farrell. Stanford, Calif.: Stanford University Press. Originally published in 2000.

Sentumbwe, Nayinda

1995 "Sighted Lovers and Blind Husbands: Experiences of Blind Women in Uganda." In Disability and Culture, edited by Benedicte Ingstad and Susan Reynolds Whyte, 159-73. Berkeley: University of California Press.

Staples, James, and Nilika Mehrotra

2016 "Disability Studies: Developments in Anthropology." In Disability in the Global South: The Critical Handbook, edited by Shaun Grech and Karen Soldatic, 35-49.

Summers, Carol Cham, Switzerland: Springer.

2006 "Radical Rudeness: Ugandan Social Critiques in the 1940s." Journal of Social History 39, no. 3: 741-70. https://doi.org/10.1353/jsh.2006.0020.

Turner, Terence

1980 “The Social Skin.” In Not Work Alone: A Cross-Cultural Survey of Activities Apparently Superfluous to Survival, edited by Jeremy Cherfas and Roger Lewin, 112-40. London: Temple Smith. 
Weiss, Brad

1996 The Making and Unmaking of the Haya Lived World: Consumption, Commoditization, and Everyday Practice. Durham, N.C.: Duke University Press.

2003 Sacred Trees, Bitter Harvests: Globalizing Coffee in Northwest Tanzania. Portsmouth, N.H.: Heinemann.

Whyte, Susan Reynolds, and Herbert Muyinda

2007 "Wheels and New Legs: Mobilization in Uganda." In Disability in Local and Global Worlds, edited by Benedicte Ingstad and Susan Reynolds Whyte, 287-310. Berkeley: University of California Press.

Whyte, Susan Reynolds, Michael A. Whyte, Lotte Meinert, and Jenipher Twebaze

2013 "Therapeutic Clientship: Belonging in Uganda's Projectified Landscape of AIDS Care." In When People Come First: Critical Studies in Global Health, edited by João Biehl and Adriana Petryna, 140-65. Princeton, N.J.: Princeton University Press.

Wool, Zoë H.

2015 After War: The Weight of Life at Walter Reed. Durham, N.C.: Duke University Press. Young, Stella

2012 "We're Not Here for Your Inspiration." Ramp Up, July 2. http://www.abc.net.au/ rampup/articles/2012/07/02/3537035.htm.

Zoanni, Tyler

2018 "The Possibilities of Failure: Personhood and Cognitive Disability in Urban Uganda." Cambridge Journal of Anthropology 36, no. 1: 61-79. https://doi. org/10.3167/cja.2018.360105. 